\title{
The Role of Macrolides for the Management of Community-Acquired Pneumonia and Pneumonia by the Novel Coronavirus SARS-CoV-2 (COVID-19): A Position Paper by Four Medical Societies from Greece
}

\author{
Evangelos J. Giamarellos-Bourboulis (D) - George L. Daikos • \\ Panagiotis Gargalianos · Charalambos Gogos • Marios Lazanas • \\ Periklis Panagopoulos • Garyphallia Poulakou · Helen Sambatakou • \\ Michael Samarkos
}

Received: March 13, 2021 / Accepted: May 26, 2021 / Published online: June 16, 2021

(c) The Author(s) 2021

\begin{abstract}
In light of the accumulating evidence for survival benefit coming from the use of macrolides for community-acquired pneumonia (CAP), a group of experts from the field of internal medicine and infectious diseases frame a position statement on the use of macrolides for the management of bacterial CAP and for infection by the novel coronavirus (COVID-19). The statement is framed taking into consideration existing publications and own research
\end{abstract}

E. J. Giamarellos-Bourboulis ( $\square)$

4th Department of Internal Medicine, ATTIKON

University Hospital, 1 Rimini Street, 12462 Athens, Greece

e-mail: egiamarel@med.uoa.gr

G. L. Daikos · M. Samarkos

1st Department of Internal Medicine, Medical School, National and Kapodistrian University of Athens, Athens, Greece

P. Gargalianos

Department of Internal Medicine, Iatriko Athinon, Athens, Greece

C. Gogos

Department of Internal Medicine, Medical School, University of Patras, Patras, Greece experience. The main content of this statement is that the combination of one $\beta$-lactam and a macrolide should be the first treatment of choice for patients with severe bacterial CAP. Severity is assessed as scoring 2 or more points on the CURB65 scoring system of severity or as pneumonia severity index III to $\mathrm{V}$ or C-reactive protein more than $150 \mathrm{mg} / \mathrm{l}$; the suggested macrolide is either azithromycin or clarithromycin. The experts also suggest that in COVID-19 pneumonia, the combination of one $\beta$-lactam and a macrolide should be reserved

\author{
M. Lazanas \\ Department of Internal Medicine, Iaso General \\ Athens Hospital, Athens, Greece \\ P. Panagopoulos \\ 2nd Department of Internal Medicine, Democritus \\ University of Thrace, Alexandroupolis, Greece \\ G. Poulakou \\ 3rd Department of Internal Medicine, Medical \\ School, National and Kapodistrian University of \\ Athens, Athens, Greece \\ H. Sambatakou \\ 2nd Department of Internal Medicine, Medical \\ School, National and Kapodistrian University of \\ Athens, Athens, Greece
}


only when there is strong suspicion of bacterial co-infection.

Keywords: Community-acquired pneumonia; COVID-19; Azithromycin; Clarithromycin; Immunomodulation

\section{Key Summary Points}

Patients presenting to the emergency department with CAP should be evaluated for severity and the need of hospitalization. CURB65, PSI and CRP are suggested as the tools of choice. Regarding CURB65, patients scoring 0-1 points can be treated as outpatients; patients scoring 2 points should be managed for $24-48 \mathrm{~h}$ under hospital supervision for probable deterioration; and patients scoring 3 points or more should be hospitalized

The first choice of treatment for patients scoring 2 or more points on CURB65 or PSI III to V or CRP more than $150 \mathrm{mg} / \mathrm{l}$ should be the combination of one $\beta$ lactam and a macrolide; the suggested macrolide is azithromycin or clarithromycin

In COVID-19 pneumonia, the combination of one $\beta$-lactam and a macrolide should be reserved only when there is strong suspicion of bacterial coinfection

\section{DIGITAL FEATURES}

This article is published with digital features, including a summary slide, to facilitate understanding of the article. To view digital features for this article go to https://doi.org/10.6084/ m9.figshare.14672379.

\section{INTRODUCTION}

The empirical management of community-acquired pneumonia (CAP) is one of the most important challenges in infectious diseases. The emerging resistance of the most common pathogens and the constantly aging population who is bearing comorbidities that increase the risk of unfavourable outcome in CAP are the main challenges.

The new guidelines for the management of CAP published by the American Thoracic Society and the Infectious Diseases Society of America (ATS/IDSA) in 2019 reintroduce the macrolide group of antibiotics as the prime tool in our armamentarium for patient management [1]. The Hellenic Sepsis Study Group (HSSG) (www.sepsis.gr) has published four booklets in the years 2008, 2011, 2014 and 2017 for the management of sepsis where the intravenous use of clarithromycin has been suggested not only for the management of CAP but also for severe sepsis by Gram-negative bacteria based on evidence coming from two randomized clinical trials (RCTs) conducted in Greek populations [2, 3]. This position of the HSSG alongside recent evidence for the salient importance of adjunctive clarithromycin therapy in CAP [4] prompted the generation of this position paper for the role of macrolides in the empirical treatment of CAP coming from four scientific societies of Greece.

\section{METHODS}

A panel of nine experts were invited to participate: one expert (PG) from the Hellenic Society for Infectious Diseases; one expert (ML) from the Hellenic Society for the Management of AIDS; three experts (CG, GLD and GP) from the Hellenic Society for Chemotherapy and four experts from the HSSG (MS, PP, HS and EJGB). These experts virtually met on 3 October 2020 where they decided that their position statement needs to cover two main aspects: (a) the 
current role of macrolides for the management of CAP and (b) the probable role of macrolides for CAP in documented infection by the novel coronavirus SARS-CoV-2 (COVID-19). During this meeting, two appointed members (EJGB and MS) presented evidence published over the last 5 years followed by discussion. It was decided that the two members would draft the first version of the statement and the main discussion points would be the core of the manuscript. The next virtual meeting took place on 12 February 2021. Before the meeting the manuscript draft was distributed to all members of the panel. During the meeting, all experts provided their comments and finalized the manuscript. The final published statement was a consensus of all meeting participants.

\section{Compliance with Ethics Guidelines}

This article is based on previously conducted studies and does not contain any new studies with human participants or animals performed by any of the authors.

\section{POSITION 1}

\section{Macrolides Have a Major Adjunctive Role and Should Always Be Included in the Starting Treatment Regimen of CAP Requiring Hospitalization}

In order to develop this position point a thorough search was conducted in the PubMed with the combination [macrolides OR azithromycin OR clarithromycin] AND pneumonia, filtering from January 2016 until January 2021. A total of 1415 article titles were retrieved. After exclusion of meta-analyses, reviews, case reports and basic research manuscripts, 11 manuscripts were retrieved; three report on macrolide resistance for respiratory pathogens; and eight are clinical studies reporting on the outcome of empirical management of CAP. A synopsis of these eight clinical studies is provided in Table 1 . All studies were conducted among patients hospitalized with CAP [4-11].
Only one of the eight studies analysed in Table 1 was a randomized clinical trial. This trial [7] was conducted in HIV-positive individuals and failed to demonstrate any survival benefit from the addition of a macrolide to ceftriaxone probably because the most of these patients had microbiologically confirmed pneumonia due to $P$. jirovecii and M. tuberculosis. In six studies the addition of a macrolide improved the outcome of the patients. In these studies, the most commonly reported pathogen was S. pneumoniae. Most of clinical benefit was for patients with severe pneumonia as this is expressed by classes IV and $\mathrm{V}$ according to the pneumonia severity index (PSI). One of the studies was a prospective cohort from Spain [9]. Multivariate analysis among patients with C-reactive protein above $150 \mathrm{mg} / \mathrm{l}$ denoted that treatment with the combination of $\beta$-lactam with a macrolide was independently associated with protection from death by pneumococcal CAP whereas the presence of septic shock and acute respiratory distress syndrome were independent drivers towards unfavourable outcome. One of the studies demonstrated that in order for the macrolide benefit to be shown, therapy should start before $\beta$-lactams [5]. The authors hypothesize that the action of $\beta$-lactams on the bacterial cell wall leads to the release of pathogenassociated molecular patterns which stimulate pro-inflammatory host responses. The preceding treatment with macrolides attenuates this pro-inflammatory effect.

One of the studies is a retrospective analysis of prospectively collected data from the HSSG. The aim of this study was not to refer to the macrolide group of antibiotics in general but to run a direct comparison of the treatment outcomes of a combination of $\beta$-lactam with clarithromycin to the combination of $\beta$-lactam and azithromycin [4]. Analysed patients had sepsis according to the Sepsis-3 definitions and comparisons to patients treated with monotherapies either with $\beta$-lactams or with moxifloxacin/ levofloxacin were done. The four groups of comparisons were fully matched using three different scores of severity (acute physiology and chronic health evaluation-APACHE II score, pneumonia severity index-PSI and sequential organ failure assessment-SOFA 
Table 1 Published clinical studies between 2016 and 2021 on the adjunctive role of macrolides for the management of severe community-acquired pneumonia (CAP)

\begin{tabular}{|c|c|c|c|c|}
\hline References & Design & Groups & $\begin{array}{l}\text { Most common } \\
\text { pathogens }\end{array}$ & Outcome measure \\
\hline$[4]$ & $\begin{array}{l}\text { Retrospective } \\
\text { analysis of } \\
\text { prospectively } \\
\text { collected data of } \\
\text { patients with } \\
\text { CAP and sepsis } \\
\text { using matching }\end{array}$ & $\begin{array}{l}\beta \text {-lactam monotherapy }=130 \\
\beta \text {-lactam plus clarithromycin }=130 \\
\beta \text {-lactam plus azithromycin }=130 \\
\text { Moxifloxacin } / \text { levofloxacin } \\
\text { monotherapy }=130\end{array}$ & Not reported & $\begin{array}{l}\text { 28-day mortality: } \\
\beta \text {-lactam } \\
\text { monotherapy }=36.8 \% \\
(p=0.009)^{*} \\
\beta \text {-lactam plus } \\
\text { clarithromycin }=20.8 \% \\
\beta \text {-lactam plus } \\
\text { azithromycin }=33.8 \% \\
(p=0.026)^{*} \\
\text { Moxifloxacin/ } \\
\text { levofloxacin } \\
\text { monotherapy }=32.8 \% \\
(p=0.049)^{*}\end{array}$ \\
\hline [5] & $\begin{array}{l}\text { Retrospective } \\
\text { analysis from the } \\
\text { CAPO database } \\
\text { of patients with } \\
\text { CAP treated with } \\
\text { macrolide/ } \beta \text { - } \\
\text { lactam } \\
\text { combination }\end{array}$ & $\begin{array}{l}\text { Macrolide start } 1 \mathrm{~h} \text { before } \beta \text { - } \\
\text { lactam }=99 \\
\text { Macrolide start } 1 \mathrm{~h} \text { after } \beta \text {-lactam }=305\end{array}$ & Not reported & $\begin{array}{l}\text { Time to clinical stability: } \\
3.5 \text { days vs } 4.3 \text { days } \\
(p=0.011)\end{array}$ \\
\hline$[6]$ & $\begin{array}{l}\text { Retrospective } \\
\text { analysis from the } \\
\text { CAPO database } \\
\text { of patients with } \\
\text { microbiologically } \\
\text { confirmed CAP }\end{array}$ & $\begin{array}{l}\text { No macrolide }=302 \\
\text { Macrolide }=247\end{array}$ & $\begin{array}{l}\text { Streptococcus } \\
\text { pneumoniae } \\
75 \%\end{array}$ & $\begin{array}{l}\text { In-hospital } 30 \text {-day } \\
\text { mortality: } \\
\text { Non-severe CAP: non- } \\
\text { macrolide } 4.4 \% ; \\
\text { macrolide } 0.7 \% ; \\
p=0.012 \\
\text { Severe CAP: non- } \\
\text { macrolide } 16.4 \% ; \\
\text { macrolide } 5.8 \% ; \\
p=0.027\end{array}$ \\
\hline
\end{tabular}


Table 1 continued

\begin{tabular}{|c|c|c|c|c|}
\hline References & Design & Groups & $\begin{array}{l}\text { Most common } \\
\text { pathogens }\end{array}$ & Outcome measure \\
\hline$[7]$ & $\begin{array}{l}\text { RCT in HIV- } \\
\text { positive } \\
\text { individuals }\end{array}$ & $\begin{array}{l}\text { Ceftriaxone }+ \text { placebo }=112 ; 20 \% \\
\text { severe } \\
\text { Ceftriaxone }+ \text { macrolide }=113 ; 15 \% \\
\text { severe }\end{array}$ & $\begin{array}{l}\text { Pneumocystis } \\
\text { jirovecii } 20 \% \\
\text { vs } 29 \% \\
\text { Mycobacterium } \\
\text { tuberculosis } \\
13 \% \text { vs } 12 \% \\
\text { Streptococcus } \\
\text { pneumoniae } \\
10 \% \text { vs } 10 \%\end{array}$ & $\begin{array}{l}\text { In-hospital mortality: } \\
\quad 11 \% \text { vs } 15 \% \\
(p=0.610) \\
14 \text {-day mortality: } 4 \% \text { vs } \\
11 \% \\
(p=0.09)\end{array}$ \\
\hline$[8]$ & $\begin{array}{l}\text { Retrospective } \\
\text { analysis of } \\
\text { prospectively } \\
\text { collected data }\end{array}$ & $\begin{array}{l}\beta \text {-lactam monotherapy }=369 \\
\beta \text {-lactam plus macrolide }=225\end{array}$ & $\begin{array}{l}\text { Streptococcus } \\
\text { pneumoniae } \\
17.9 \% \text { vs } \\
18.2 \% \\
\text { Klebsiella } \\
\text { pneumoniae } \\
15.4 \% \text { vs } \\
9.3 \%\end{array}$ & $\begin{array}{l}\text { 30-day mortality: } 13.8 \% \\
\text { vs } 1.8 \%(p<0.001) \\
\text { Early treatment failure: } \\
18.4 \% \text { vs } 7.6 \% \\
\text { ( } p<0.001) \\
\text { LOS: } 16 \text { days vs } 10 \text { days } \\
(p<0.001)\end{array}$ \\
\hline [9] & Prospective cohort & $\begin{array}{l}\beta \text {-lactam plus macrolide }=932 \text {; severe } \\
57 \% \\
\text { Fluoroquinolone } \pm \beta \text {-lactam }=783 \text {; } \\
\text { severe } 60 \%\end{array}$ & $\begin{array}{l}\text { Streptococcus } \\
\text { pneumoniae } \\
45 \% \text { vs } 44 \% \\
\text { Polymicrobial } \\
16 \% \text { vs } 12 \%\end{array}$ & $\begin{array}{l}\text { 30-day mortality } \\
\text { Overall } 5 \% \text { vs } 8 \% \\
(p=0.015) \\
\text { Pneumococcal } \\
\text { pneumonia } 4 \% \text { vs } 9 \% \\
(p=0.004) \\
\text { CRP }>150 \mathrm{mg} / 13 \% \text { vs } \\
8 \%(\mathrm{p}<0.001)\end{array}$ \\
\hline$[10]$ & $\begin{array}{l}\text { Retrospective } \\
\text { analysis of } \\
\text { prospectively } \\
\text { collected data of } \\
\text { patients with } \\
\text { CAP and sepsis } \\
\text { using propensity } \\
\text { score matching }\end{array}$ & $\begin{array}{l}\beta \text {-lactam plus azithromycin }=560 \\
\beta \text {-lactam plus levofloxacin }=560\end{array}$ & Not reported & $\begin{array}{l}\text { 28-day mortality: } 19.3 \% \\
\quad \text { vs } 20.7 \%(p=0.601) \\
\text { In-hospital mortality: } \\
24.8 \% \text { vs } 26.8 \% \\
(p=0.495)\end{array}$ \\
\hline
\end{tabular}


Table 1 continued

\begin{tabular}{lllll}
\hline References & Design & Groups & $\begin{array}{l}\text { Most common } \\
\text { pathogens }\end{array}$ & Outcome measure \\
\hline$[11]$ & Open-label quasi- & Ceftriaxone + clarithromycin & $\begin{array}{c}\text { Streptococcus } \\
\text { pneumoniae }\end{array}$ & Efficacy end-of- \\
& treatment: $57 \%$ vs $94 \%$ \\
& AmpT & $33.6 \%$ vs & $(p=0.055)$ \\
& $(n=104) ; 22 \%$ severe & $24.1 \%$ & \\
& & Mycoplasma & \\
& & pneumoniae & \\
& & $36.5 \%$ vs & \\
& & $25.9 \%$ & \\
& & & \\
& & & \\
& & &
\end{tabular}

CAPO database of hospitalized patients with CAP from 83 hospitals in 16 countries, CRP C-reactive protein, LOS length of hospital stay, $n$ number of patients, $R C T$ randomized clinical trial, $v s$ versus

${ }^{*} p$ values refer to comparisons with the $\beta$-lactam plus clarithromycin group

score), Charlson's comorbidity index and the type of administered $\beta$-lactam. There was a profound survival benefit of the combination of $\beta$-lactam with clarithromycin (28-day mortality $20.8 \%$ ) over the combination of $\beta$-lactam with azithromycin (28-day mortality 33.8\%; $p$ of comparison 0.026). This benefit of the combination of $\beta$-lactam with clarithromycin was also found over the other two groups of treatment.

These results corroborate information coming from two meta-analyses published before 2016. The first analysed 16 observational studies and found that the addition of a macrolide to one $\beta$-lactam was associated with cumulative odds ratio for mortality $0.67(0.61-0.73)$. The same meta-analysis reported that the benefit was larger for severe patients and for CAP due to $S$. pneumoniae [12]. The second meta-analysis was based on 16 studies; 13 observational studies and 3 RCTs. The meta-analysis showed survival benefit with the combination of one $\beta$ lactam and a macrolide, but only when the observational studies were included. The explanation provided by the authors was that patients participating in the RCTs had lower severity [13]. One of these RCTs compared the impact of the addition of clarithromycin versus placebo to $\beta$-lactams for the achievement of clinical stability after 7 days of treatment. Although the study was designed as a non- inferiority trial, the authors failed to prove their non-inferior hypothesis; by day $7,41.2 \%$ of patients treated with $\beta$-lactam and placebo were still unstable compared to $33.6 \%$ of patients treated with $\beta$-lactam and clarithromycin [14].

The benefit shown with macrolide adjunctive treatment may be explained by the immunomodulatory effect on the pro-inflammatory response of the host. It is very difficult to provide robust evidence of this effect in a clinical setting. The main obstacle is the antibacterial activity of macrolides against implicated pathogens which does not allow one to clearly conclude whether the benefit derives from the antimicrobial or from the immunomodulatory activity. In an attempt to decipher this, two RCTs were conducted among patient populations with infections by Gramnegative bacteria that are not included in the macrolide antimicrobial spectrum. In both trials, the studied macrolide was clarithromycin. The first study was conducted in 200 Greek patients with ventilator-associated pneumonia (VAP) [2] and the other in 600 Greek patients with Gram-negative infections and systemic inflammatory response syndrome (SIRS) [3]. The study of patients with VAP showed major survival benefit after 90 days; survival was $40 \%$ among patients treated with placebo and standard-of-care (SOC) antibiotics and 57\% among 
patients treated with clarithromycin and SOC antibiotics ( $p=0.023$ ) [2]. The study of patients with SIRS due to Gram-negative infections showed most of the survival benefit after 28 days among patients with septic shock and multiple organ dysfunction [3]. A randomized clinical trial of oral Clarithromycin in Community-acquired pneumonia to attenuat $E$ inflammatory respons $E$ and improve outcomeS (ACCESS) is the first on-going RCT that has been designed to study the potential of clarithromycin to modulate the inflammatory response of the host in severe pneumonia. Participants have CAP aggravated by sepsis defined by the Sepsis-3 definitions, at least two signs of SIRS and procalcitonin more than or equal to $0.25 \mathrm{ng} / \mathrm{ml}$; they are blindly randomized to treatment with placebo and ceftriaxone or clarithromycin and ceftriaxone. The primary endpoint is early response after $72 \mathrm{~h}$ defined by decrease of the baseline respiratory symptoms score and at least $30 \%$ decrease of the baseline SOFA score or at least $80 \%$ decrease of the baseline procalcitonin (EudraCT 2020-00445215; Clinicaltrials.gov NCT04724044).

It is the feeling of the panel that the data of the clinical efficacy of macrolides should be interpreted with caution in the light of the prevalence of resistant isolates which differs considerably from one geographic region to the other. This variation in prevalence is between $19.4 \%$ and $72 \%$ for the invasive isolates [15-17] and between $34.3 \%$ and $98.2 \%$ for the non-invasive isolates of S. pneumoniae [18, 19]. The 2019 ATS/IDSA guidelines clearly distinguish between patients in need of hospitalization and those in need of outpatient management. Their first suggestion for patients in need of hospitalization is the combination of one $\beta$-lactam with a macrolide. For outpatient treatment, the suggestion relies on the presence of risk factors such as chronic heart failure, chronic renal disease, chronic obstructive pulmonary disease and liver cirrhosis. In the absence of these risk factors, guidelines suggest that macrolide monotherapy should be reserved for communities with resistance rates of less than $25 \%$. In the presence of these risk factors, the guideline favours the use of the combination of one $\beta$ lactam with a macrolide [1].
A balance should be applied in everyday clinical practice between the excess use of macrolides in CAP and the need to reserve them where there is real clinical demand. The need for this balance comes from the risk of the emergence of macrolide resistance in the case of excess prescription. The real benefit from the adjunctive use of macrolides to $\beta$-lactams in CAP is for severe patients. Although severity can easily be assessed by using bedside signs of instability like hypotension, mental deterioration and excess breathing [20], it is also expressed by clinical scores like PSI and CURB65 that can be used for the early prediction of the risk for unfavourable outcome. In a systemic review of eight studies, high risk for death was found for patients with PSI classes IV and V and for patients with CURB65 2 or more [21]. In the ProHOSP cohort, 925 patients with CAP were followed up for 5 years; 417 were non-survivors. Survival analysis showed that patients with PSI III or more and CURB65 1 or more were at the greatest likelihood for death during the first year. Patients distributed to the upper quartile of values CRP were also at high risk of death [22]. We suggest that PSI III or more, CURB65 2 or more and CRP more than $150 \mathrm{mg} / \mathrm{l}$ should be used as predictors of severity alongside haemodynamic instability (Fig. 1).

Comment 1 (CG) Existing data on the ability of macrolides to modulate the exaggerated response of the host are impressive. These are further enhanced by the improvement of the outcome of patients with severe infections by Gram-negative bacteria against which macrolides are inactive.

Comment $2(P G)$ In the light of the analysed data, I feel that most of the benefit from the addition of macrolides is for patients with CAP in need of hospitalization. This is associated with the beneficial action on the attenuation of SIRS. We should also consider that most of patients treated as outpatients receive most benefit with $\beta$-lactam monotherapy. However, as far intravenous administration is concerned clarithromycin induces superficial thrombophlebitis at a greater rate than azithromycin. In addition, when compared to fluoroquinolones for use for respiratory infections, namely moxifloxacin and levofloxacin, patients 


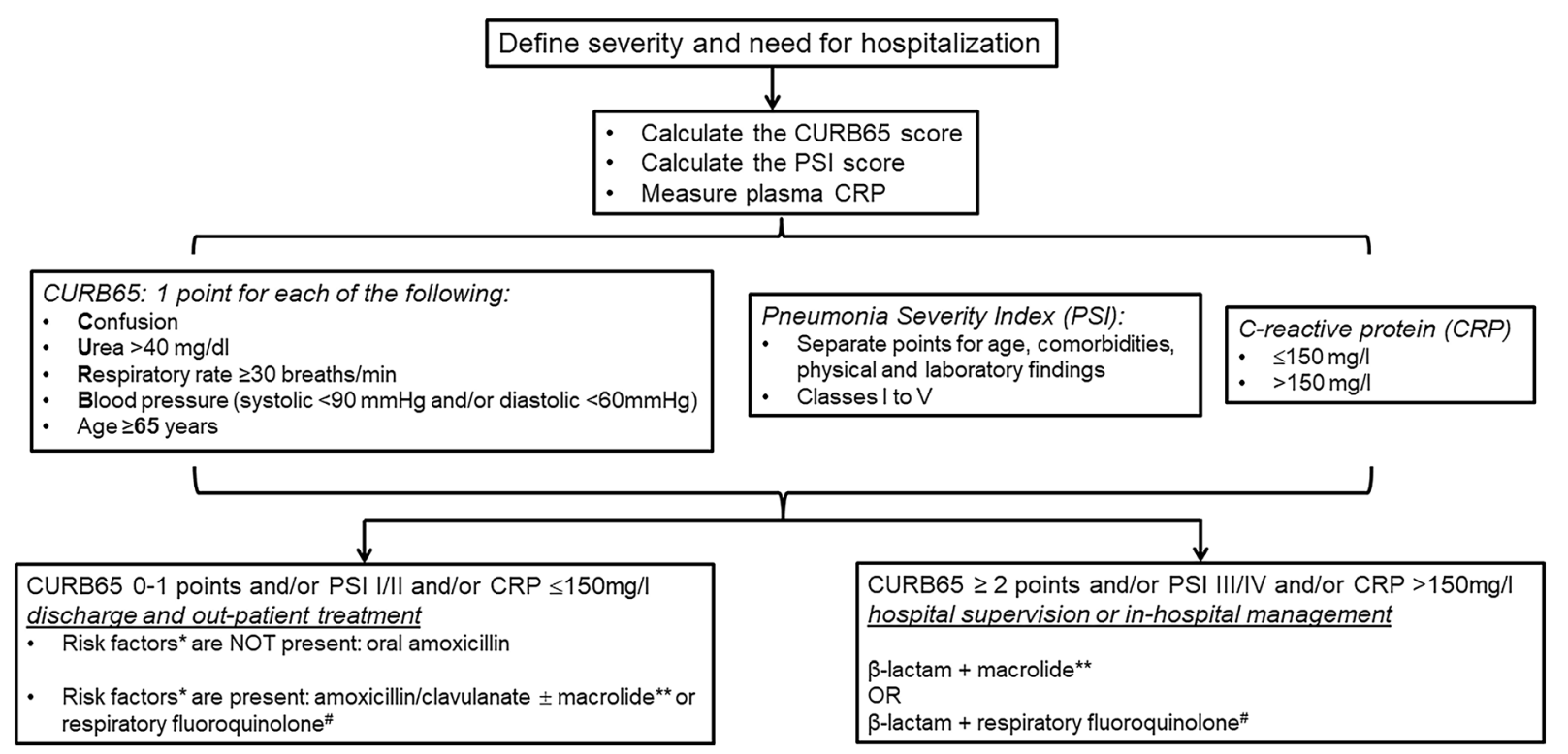

Fig. 1 The positions of macrolides in the management algorithm of community-acquired pneumonia. *Risk factors: chronic heart failure, chronic obstructive pulmonary disease, chronic liver disease, chronic renal disease, diabetes mellitus, alcoholism, malignancy, asplenia. ${ }^{* *}$ Suggested

treated with macrolides present with fewer adverse events on the cardiovascular system like QTc prolongation and aneurysm rupture [23]. These are reasons making respiratory fluoroquinolones less popular for respiratory tract infections than macrolides among the medical community.

Comment 3 (ML) We need to remember that the selection of patients for hospitalization should rely on the CURB65 score and that amoxicillin remains the $\beta$-lactam of choice for outpatient management. A recent analysis of 725 patients with CAP admitted at the emergency department were classified into low risk, intermediate risk and high risk for unfavourable outcome according to the presentation of $0-1$ points, 2 points and 3 or more points on CURB65. Mortality after 28 days was $5.8 \%$, $13.5 \%$ and $27.0 \%$, respectively [24].

Comment 4 (GP) It should never be ignored that a major role for the inclusion of macrolides in the treatment regimen of bacterial CAP is the implication of atypical pathogens against which macrolides are active. The use of molecular detection techniques has revealed their macrolide: azithromycin $500 \mathrm{mg}$ once daily for 5 days or clarithromycin $500 \mathrm{mg}$ twice daily for 7 days. ${ }^{\#}$ Suggested quinolone: moxifloxacin or levofloxacin

presence in $10-30 \%$ of severe CAP and this is a fair reason for the co-administration of macrolides with $\beta$-lactams.

The position of the expert panel for the role of macrolides for the management of CAP is shown in the algorithm in Fig. 1.

\section{POSITION 2}

\section{Position of Macrolides in Empirical Treatment of COVID-19}

Early in the course of the COVID-19 pandemic, azithromycin and hydroxychloroquine were introduced in the empirical treatment of patients. This was based on the results of an open-label non-randomized trial of 36 patients, 6 of whom were treated with this combination; the study showed faster viral clearance in comparison with a control group [25]. However, the limited number of patients and the selection of the control group raised serious concerns for the efficacy of this combination. The limited efficacy of azithromycin became evident when the 
results of the randomized clinical trials were published. A summary of these results is provided in Table 2 [26-28]. All three trials are open-label and randomized in design. The first trial showed improvement of oxygen saturation at hospital discharge [26] whereas the other two trials enrolling much greater numbers of patients failed to disclose any efficacy from azithromycin treatment $[27,28]$.

There are several studies showing benefit from the use of macrolides in cell systems of viral infections. These studies either demonstrate attenuation of the inflammatory response or inhibition of viral entry into airway epithelial cells. Although rhinoviruses were used as infective agents in the cell systems, results were extrapolated to SARS-CoV-2. The addition of azithromycin in a cell system by large-sized and small-sized airway epithelial cells in vitro infected by the rhinovirus RV1b decreased viral replication after 24 and $48 \mathrm{~h}$; this was accompanied by reciprocal decrease of the concentrations of interleukin (IL)-6, of IL-8 and of RANTES in cell supernatants [29]. The decrease of viral replication may be mediated through stimulation of the production of the antiviral interferons I and III effected through the addition of macrolides in the growth medium [30].

Three in vitro studies support that the mode of action of macrolides may be associated with the prevention of viral entry into the airway epithelial cells. In the first study, nasal epithelial cells were isolated from excised nasal specimens during surgery of 15 patients with asthma and 12 patients without asthma. Cells were pretreated with clarithromycin and then infected with rhinovirus RV14. Results showed a decrease of the relative amount of viral RNA in the cell with a parallel decrease of ICAM-1 (intercellular adhesion molecule 1) that facilitates viral entry into the cells. This finding alongside a decrease of cell vacuolization favoured inhibition of viral entry in the nasal epithelial cells by clarithromycin [31]. In the second study, epithelial cell lines were infected with pseudovirus mimicking SARS-CoV-2 in the presence of increasing concentrations of azithromycin. The cell infection rate was reduced and this was associated with an increase of the acidification of the intracellular vesicles containing the virus
[32]. In line with this, treatment of nasal epithelial cells with azithromycin modulated gene expression towards downregulation of endocytosis pathways associated with TMPRSS2 and TMPRSS11D encoding the serine proteases that are necessary for the entry of SARS-CoV-2 into the epithelial cell [33].

These results from in vitro culture systems suggest that the main mode of action of macrolides is associated with the modulation of the machinery of the airway epithelial cells so that they resist invasion by SARS-CoV-2. As a consequence, there may be a window over the time course of COVID-19 where the use of macrolides is of major benefit. The findings of the open-label non-randomized ACHIEVE trial in 90 patients with moderate COVID-19 are in line with this hypothesis. In the ACHIEVE trial (Anti-inflammatory ClaritHromycin to ImprovE SARS-CoV-2 Infection Early) 90 patients were treated orally with clarithromycin $500 \mathrm{mg}$ twice daily for 7 days; co-administration of hydroxychloroquine/chloroquine phosphate was not allowed (EudraCT number 2020-001882-36; National Ethics Committee approval 45/20; National Organization for Medicines approval ISO 36/20; ClinicalTrials.gov NCT04398004). Results of the study have not yet been published but they are available as a preprint [34]. The primary study endpoint was defined as at least $50 \%$ decrease of the respiratory symptoms score for participants with lower respiratory tract infection or as no hospital readmission for participants with upper respiratory tract infection. This was achieved in $91.7 \%$ of patients starting clarithromycin in the first 5 days from symptoms onset and in $81.4 \%$ of patients starting clarithromycin later than 5 days from symptoms onset. This association of the achievement of the primary endpoint with the delay in start of treatment was found only for patients infected by the B1.1. European variant of SARS-CoV-2; patients infected by other variants had similar benefit irrespective of treatment delay. Significant decrease of the viral load was found over time of treatment. The decrease of the viral load in the nasopharynx of patients at the end of treatment was greater among patients who had enhanced Th1 responses. 
Table 2 Prospective trials of the use of macrolides for the management of COVID-19

\begin{tabular}{|c|c|c|c|c|c|c|}
\hline References & Design & $\begin{array}{l}\text { Baseline } \\
\text { severity }\end{array}$ & $\begin{array}{l}\text { Groups of } \\
\text { treatment }(n)\end{array}$ & $\begin{array}{l}\text { Primary } \\
\text { endpoint }\end{array}$ & $\begin{array}{l}\text { Main secondary } \\
\text { endpoints }\end{array}$ & $\begin{array}{l}\text { Serious adverse } \\
\text { events }\end{array}$ \\
\hline [26] & $\begin{array}{l}\text { Open-label, } \\
\text { randomized }\end{array}$ & $\begin{array}{l}\text { Hospitalized, } \\
\text { severe }\end{array}$ & $\begin{array}{l}\text { Control (56): } \\
\text { (LPV/r } \\
400 / 100 \mathrm{mg} \\
\text { bid + HCQ } \\
400 \mathrm{mg} \mathrm{qd} \text { ) for } \\
5 \text { days } \\
\text { Case (55): (AZM } \\
500 \mathrm{mg} \text { qd } \\
\mathrm{LPV} / \mathrm{r} \\
400 / 100 \mathrm{mg} \\
\text { bid + HCQ } \\
400 \mathrm{mg} \mathrm{qd} \text { ) for } \\
5 \text { days }\end{array}$ & $\begin{array}{l}\text { Mean hospital } \\
\text { stay: } 5.96 \text { days } \\
\text { vs } 4.61 \text { days } \\
(p=0.020) \\
\text { Need for ICU } \\
\text { admission: } 7 \% \\
\text { vs } 2 \% \\
(p=0.070) \\
\text { Death: } 1 \% \text { vs } 0 \% \\
(p=0.495)\end{array}$ & $\begin{array}{l}\text { Discharge } \mathrm{SpO} 2: \\
92.4 \% \text { vs } 93.9 \% \\
(p=0.030) \\
\text { Discharge } \\
\text { respiratory rate: } \\
17.4 \text { vs } 15.8 \\
\text { breaths } / \text { min vs } \\
(p=0.010)\end{array}$ & NR \\
\hline [27] & $\begin{array}{l}\text { Open-label, } \\
\text { randomized }\end{array}$ & $\begin{array}{l}\text { Hospitalized, } \\
\text { mild to } \\
\text { moderate }\end{array}$ & $\begin{array}{l}\text { SOC (227) } \\
\text { SOC + HCQ } \\
400 \text { mg bid for } \\
7 \text { days (221) } \\
\text { SOC + AZM } \\
500 \mathrm{mg} \\
\text { qd + HCQ } \\
400 \text { mg bid for } \\
7 \text { days }(217)\end{array}$ & $\begin{array}{l}\text { Median (IQR) } \\
7 \text {-level ordinal } \\
\text { outcome at } \\
15 \text { days*: } 1 \\
(1-2), 1(1-2) \text {, } \\
1(1-2)\end{array}$ & $\begin{array}{l}\text { Need of } \\
\text { mechanical } \\
\text { ventilation: } \\
6.9 \% \text { vs } 7.5 \% \text { vs } \\
11.0 \% \\
\text { In-hospital death: } \\
3.5 \% \text { vs } 4.4 \% \text { vs } \\
2.9 \% \\
\text { Thromboembolic } \\
\text { complications: } \\
1.2 \% \text { vs } 1.9 \% \text { vs } \\
1.2 \% \\
\text { Acute kidney } \\
\text { injury: } 2.9 \% \text { vs } \\
2.5 \% \text { vs } 3.5 \%\end{array}$ & $\begin{array}{l}\text { HCQ + AZM: } \\
2.1 \% \\
\text { HCQ: } 1 \% \\
\text { AZM: } 0 \%\end{array}$ \\
\hline
\end{tabular}


Table 2 continued

\begin{tabular}{|c|c|c|c|c|c|c|}
\hline References & Design & $\begin{array}{l}\text { Baseline } \\
\text { severity }\end{array}$ & $\begin{array}{l}\text { Groups of } \\
\text { treatment }(\mathbf{n})\end{array}$ & $\begin{array}{l}\text { Primary } \\
\text { endpoint }\end{array}$ & $\begin{array}{l}\text { Main secondary } \\
\text { endpoints }\end{array}$ & $\begin{array}{l}\text { Serious adverse } \\
\text { events }\end{array}$ \\
\hline [28] & $\begin{array}{l}\text { Open-label, } \\
\text { randomized }\end{array}$ & $\begin{array}{l}\text { Hospitalized, } \\
\text { severe }\end{array}$ & $\begin{array}{l}\text { SOC (183) } \\
\text { SOC + AZM } \\
500 \mathrm{mg} \text { qd for } \\
10 \text { days }(214)\end{array}$ & $\begin{array}{l}\text { Difference in } \\
\text { score of } \\
\text { 6-point } \\
\text { ordinal scale at } \\
\text { day 15: } 1.36 \\
(0.94-1.97) \\
(p=0.110)\end{array}$ & $\begin{array}{l}\text { Death at } 29 \text { days: } \\
40 \% \text { vs } 42 \% \\
(p=0.630) \\
\text { LOS of survivors: } \\
18 \text { days vs } \\
26 \text { days } \\
(p=0.064) \\
\text { Secondary } \\
\text { infections: } 36 \% \\
\text { vs } 41 \% \\
(p=0.290)\end{array}$ & $\begin{array}{l}38 \% \text { vs } 42 \% \\
\quad(p=0.350)\end{array}$ \\
\hline
\end{tabular}

$A Z M$ azithromycin, bid two times daily, $H C Q$ hydroxychloroquine, $I C U$ intensive care unit, $L O S$ length of hospital stay, $L P V / r$ lopinavir/ritonavir, $n$ number of patients, NR not reported, $q d$ once daily, SAEs serious adverse events, SOC standard-of-care, $\mathrm{SpO}_{2}$ oxygen saturation, $v s$ versus

*The levels of the scale are defined as follows: (1) not hospitalized with no limitation in activities; (2) not hospitalized with limitation in activities; (3) hospitalized and not receiving supplementary oxygen; (4) hospitalized and receiving supplementary oxygen; (5) hospitalized and receiving supplementary oxygen by high-flow nasal cannula or non-invasive ventilation; (6) hospitalized and receiving mechanical ventilation; (7) death

Comment 1 (HS) I would like to address two main arguments in favour of the use of azithromycin in patients with COVID-19. The first argument is the results of an RCT where patients with influenza A and B were randomized to oral treatment with oseltamivir $75 \mathrm{mg}$ twice daily for 5 days ( $n=25$ patients) or oral administration of a combination of azithromycin $500 \mathrm{mg}$ once daily and oseltamivir $75 \mathrm{mg}$ twice daily for 5 days $(n=25)$. The study was successful in the primary endpoint which was an attenuation of the systemic inflammatory response as this was found by the decrease of circulating IL-6, IL-8 and IL-17 over time [35]. The second argument is the in vitro evidence that azithromycin interacts with the CD147 receptor of SARS-CoV-2 and does not allow viral entry into the airway epithelial cells [36].

Comment 2 (GP) The difference in half-life of clarithromycin compared to azithromycin may be of major importance for administration in COVID-19 pneumonia. The empirical overconsumption of antibiotics during the COVID-19 era may lead to substantial induction of resistance, and antibiotics with longer half-life, like azithromycin, are more likely to induce resistant floras.

Comment 3 (GD) The lack of positive results from RCTs on the use of azithromycin for COVID-19 narrows the indication of co-administration of $\beta$-lactams and macrolides only for patients with COVID-19 and strong suspicion of bacterial co-infection.

\section{REPORTED ON-GOING CHALLENGES}

Point 1 (CG) The results of published clinical trials discourage the use of azithromycin for the management of COVID-19. The results of the ACHIEVE study demonstrate the importance of the administration of clarithromycin in the modulation of the response of the host. The enhancement of the antiviral efficacy of 
macrolides in co-administration of remdesivir is a point of further research.

Point $2(P G)$ The time point of start of treatment seems to be a salient factor for successful management. COVID-19 bears the features of viral infections necessitating intervention at zero time, if probable. The benefit shown from the ACHIEVE trial from early start of clarithromycin is a promising result.

The position of the expert panel for the mechanism of action of macrolides in COVID19 pneumonia is shown in Fig. 2.

\section{FINAL STATEMENT}

Taking into consideration all the positions and the points of discussion, the following position statement was agreed by all experts:

\section{Th1-cells, NK cells}
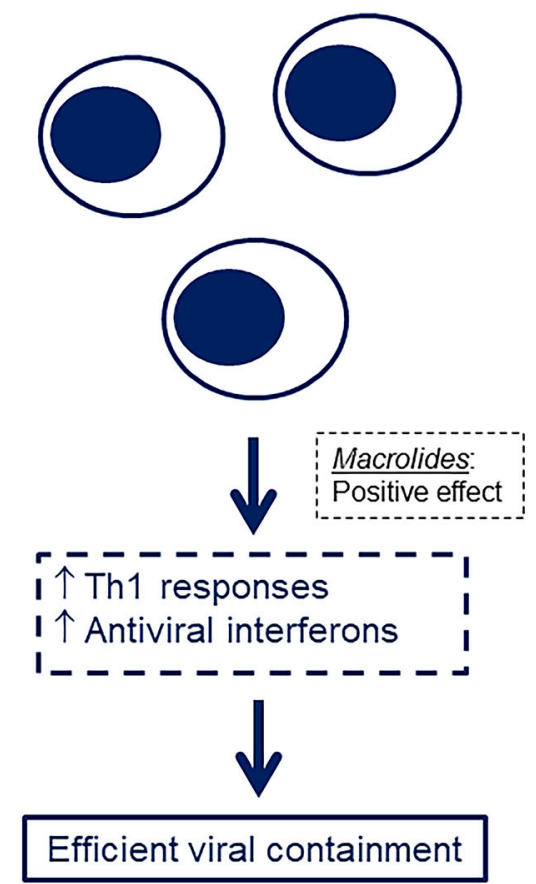

Fig. 2 Suggested mechanism of macrolide action in COVID-19 pneumonia. Macrolides may act either at the levels of Th1 lymphocytes and NK cells or at the levels of
- Patients presenting to the emergency department with CAP should be evaluated for severity and the need of hospitalization. CURB65, PSI and CRP are suggested as the tools of choice. Regarding CURB65 patients scoring $0-1$ points can be treated as outpatients; patients scoring 2 points should be managed for $24-48 \mathrm{~h}$ under hospital supervision for probable deterioration; and patients scoring 3 points or more should be hospitalized.

- The first choice of treatment for patients scoring 2 or more points by CURB65 or PSI III to V or CRP more than $150 \mathrm{mg} / \mathrm{l}$ should be the combination of one $\beta$-lactam and a macrolide; the suggested macrolide is azithromycin or clarithromycin.

- In COVID-19 pneumonia, the combination of one $\beta$-lactam and a macrolide should be

\section{AIRWAY EPITHELIUM}

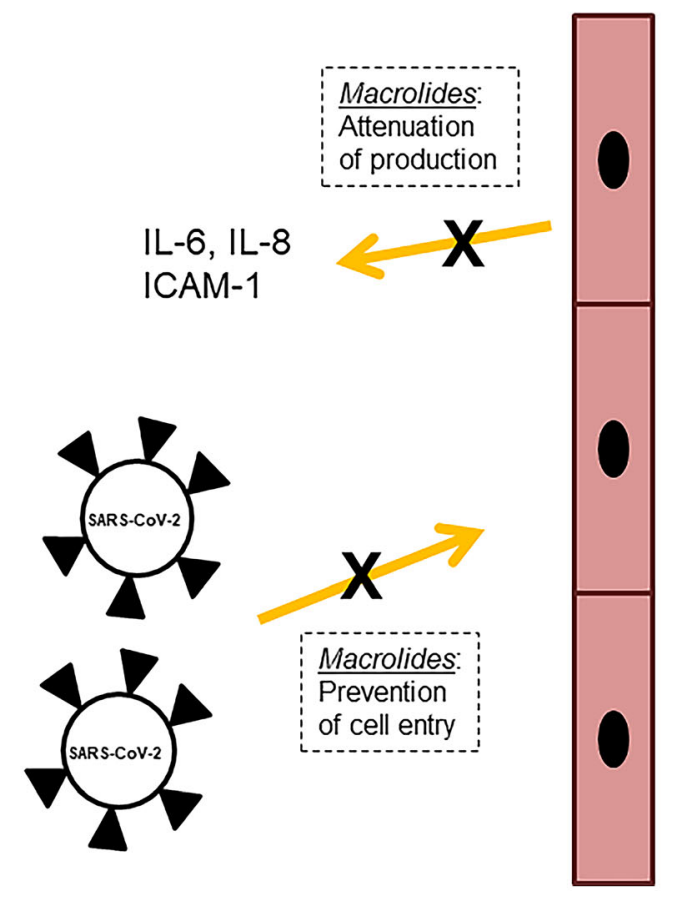

airway epithelium. The mechanism of action is shown in dashed outlined boxes. $\uparrow$ increase, ICAM intracellular adhesion molecule, IL interleukin 
reserved only when there is strong suspicion of bacterial co-infection.

\section{ACKNOWLEDGEMENTS}

Funding. The study was funded by the Hellenic Institute for the Study of Sepsis. No Rapid Service Fee was received by the journal for the publication of this article.

Authorship. All named authors meet the International Committee of Medical Journal Editors (ICMJE) criteria for authorship for this article, take responsibility for the integrity of the work as a whole, and have given their approval for this version to be published.

Authorship Contributions. EJGB conceptualized the study, wrote the manuscript and provided approval for the final version to be submitted. GLD, PG, CG, ML, PP, GP and HS participated in the exchange of positioning, critically reviewed the manuscript and provided approval for the final version to be submitted. MS contributed in literature acquisition, drafted the manuscript and provided approval for the final version to be submitted.

Disclosures. Evangelos J. Giamarellos-Bourboulis has received honoraria from Abbott $\mathrm{CH}$, InflaRx GmbH, MSD Greece, XBiotech Inc. and Angelini Italy; independent educational grants from AbbVie, Abbott, Astellas Pharma Europe, AxisShield, bioMérieux Inc, InflaRx $\mathrm{GmbH}$, and XBiotech Inc.; and funding from the Horizon2020 Marie-Curie Project European Sepsis Academy (granted to the National and Kapodistrian University of Athens), and the Horizon 2020 European Grants ImmunoSep and RISKinCOVID (granted to the Hellenic Institute for the Study of Sepsis). Periklis Panagopoulos has received honoraria from GILEAD Sciences, Janssen, and MSD. Garyphallia Poulakou has received independent educational grants from Pfizer, MSD, Angelini, and Biorad. George L. Daikos, Panagiotis Gargalianos, Charalambos Gogos, Marios Lazanas, Helen
Sambatakou and Michael Samarkos have nothing to disclose.

Compliance with Ethics Guidelines. This article is based on previously conducted studies and does not contain any new studies with human participants or animals performed by any of the authors.

Data Availability. Data sharing is not applicable to this article as no datasets were generated or analyzed during the current study.

Open Access. This article is licensed under a Creative Commons Attribution-NonCommercial 4.0 International License, which permits any non-commercial use, sharing, adaptation, distribution and reproduction in any medium or format, as long as you give appropriate credit to the original author(s) and the source, provide a link to the Creative Commons licence, and indicate if changes were made. The images or other third party material in this article are included in the article's Creative Commons licence, unless indicated otherwise in a credit line to the material. If material is not included in the article's Creative Commons licence and your intended use is not permitted by statutory regulation or exceeds the permitted use, you will need to obtain permission directly from the copyright holder. To view a copy of this licence, visit http://creativecommons.org/licenses/by$\mathrm{nc} / 4.0 /$.

\section{REFERENCES}

1. Metlay JP, Waterer GW, Long AC, et al. Diagnosis and treatment of adults with community-acquired pneumonia. Am J Resp Crit Care Med. 2019;200: e45-67.

2. Tsaganos T, Raftogiannis M, Pratikaki M, et al. Clarithromycin leads to long-term survival and cost benefit in ventilator-associated pneumonia and sepsis. Antimicrob Agents Chemother. 2016;60: 3640-6.

3. Giamarellos-Bourboulis EJ, Mylona V, Antonopoulou A, et al. Effect of clarithromycin in patients with suspected Gram-negative sepsis: results of a 
randomized controlled trial. J Antimicrob Chemother. 2014;69:1111-8.

4. Kyriazopoulou E, Sinapidis D, Halvatzis S, et al. Survival benefit associated with clarithromycin in severe community-acquired pneumonia: a matched comparator study. Int $\mathrm{J}$ Antimicrob Agents. 2020;55:105836.

5. Peyrani P, Wiemken TL, Metersky ML, et al. The order of administration of macrolides and betalactams may impact the outcomes of hospitalized patients with community-acquired pneumonia: results from the community-acquired pneumonia organization. Infect Dis. 2018;50:13-20.

6. Arnold FW, Lopardo G, Wiemken TL, et al. Macrolide therapy is associated with lower mortality in community-acquired bacteraemic pneumonia. Resp Med. 2018;140:115-21.

7. Figueiredo-Mello C, Nauclier P, Negra MD, Levin AS. Ceftriaxone versus ceftriaxone plus a macrolide for community-acquired pneumonia in hospitalized patients with HVI/AIDS: a randomized controlled trial. Clin Microbiol Infect. 2018;24:146-51.

8. Okumura J, Shindo Y, Takahashi K, et al. Mortality in patients with community-onset pneumonia at low risk of drug-resistant pathogens: impact of $\beta$ lactam plus macrolide combination therapy. Respirology. 2018;23:526-34.

9. Ceccato A, Colloniz C, Martin-Loeches I, et al. Effect of combined $\beta$-lactam/macrolide therapy on mortality according to the microbial etiology and inflammatory status of patients with communityacquired pneumonia. Chest. 2019;155:795-804.

10. Suzuki J, Sasabuchi Y, Hatakeyama S, et al. Azithromycin plus $\beta$-lactam versus levofloxacin plus $\beta$ lactam for severe community-acquired pneumonia: a retrospective nationwide database analysis. J Infect Chemother. 2019;25:1012-8.

11. Hamao N, Ito I, Konishi S, et al. Comparison of ceftriaxone plus macrolide and amplicillin/sulbactam plus macrolide in treatment for patients with community-acquired pneumonia without risk factors for aspiration: an open-label, quasi- randomized, controlled trial. BMC Pulm Med. 2020;20:160.

12. Nie W, Li B, Xiu Q. $\beta$-Lactam/macrolide dual therapy versus $\beta$-lactam monotherapy for the treatment of community-acquired pneumonia in adults: a systematic review and meta-analysis. J Antimicrob Chemother. 2014;69:1441-6.

13. Horita N, Otsuka T, Haranaga S, et al. Beta-lactam plus macrolides or beta-lactam alone for community-acquired pneumonia: a systematic review and meta-analysis. Respirology. 2016;21:1193-200.
14. Garin N, Genné D, Carballo S, et al. $\beta$-lactam monotherapy vs $\beta$-lactam-macrolide combination treatment in moderately severe community-acquired pneumonia: a randomized non-inferiority trial. JAMA Intern Med. 2014;174:1894-901.

15. Maraki S, Mavrogeorgaki VE, Stafylaki D, et al. The evolving epidemiology of serotype distribution and antimicrobial resistance of Streptococcus pneumoniae strains isolated from adults in Crete, Greece 2009-2016. Infect Chemother. 2018;50:328-39.

16. Rahbar M, Dehkhargani AD, Zahraei SM, et al. Antimicrobial resistance in Streptococcus pneumoniae isolates from invasive pneumococcal infections in Iran. J Glob Antimicrob Res. 2019;16:260-1.

17. Golden AR, Baxter MR, Davidson RJ, et al. Comparison of antimicrobial resistance patterns in Streptococcus pneumoniae from respiratory and blood cultures in Canadian hospitals from 2007-2016. J Antimicrob Chemother. 2019;74(Suppl 4):iv39.

18. Cai K, Wang Y, Guo Z, et al. Clinical characteristics and antimicrobial resistance of pneumococcal isolates of pediatric invasive pneumococcal disease in China. Infect Drug Res. 2018;11:2461-9.

19. Batool S, Almaghaslah D, Alqahtani A, et al. Aetiology and antimicrobial susceptibility pattern of bacterial isolates in community acquired pneumonia patients at Asir region, Saudi Arabia. Int J Clin Pract. 2021;75:e13667.

20. Kesselmeier M, Pletz MW, Blankenstein AL, et al. Validation of the qSOFA score compared to the CRB-65 score for risk prediction in community-acquired pneumonia. Clin Microbiol Infect. 2020. https://doi.org/10.1016/j.cmi.2020.10.008.

21. Noguchi S, Yatera K, Kawanami T, et al. Pneumonia severity assessment tools for predicting mortality in healthcare-associated pneumonia: a systemic review and meta-analysis. Respiration. 2017;93: 441-50.

22. Alan M, Grolimund E, Katz A, et al. Clinical risk scores and blood biomarkers as predictors of longterm outcome in patients with community-acquired pneumonia: a 6-year prospective follow-up study. J Intern Med. 2015;278:174-84.

23. Bennett AC, Bennett CL, Witherspoon BJ, Knopf $\mathrm{KB}$. An evaluation of reports of ciprofloxacin, levofloxacin, and moxifloxacin-association neuropsychiatric toxicities, long-term disability, and aortic aneurysms/dissections disseminated by the Food and Drug Administration and the European Medicines Agency. Expert Opin Drug Saf. 2019;18: 1055-63. 
24. Roest AA, Tegtmeier J, Heyligen JJ, et al. Risk stratification by abbMEDS and CURB-65 in relation to treatment and clinical disposition of the septic patient at the emergency department: a cohort study. BMC Emerg Med. 2015;15:29.

25. Echeverría-Esnal D, Martin-Ontiyelo C, NavarreteRouco ME, et al. Azithromycin in the treatment of COVID-19: a review. Exp Rev Anti-Infect Ther. 2020. https://doi.org/10.1080/14787210.2020. 1813024.

26. Sekhavati E, Jafari F, SeyedAlinaghi S, et al. Safety and effectiveness of azithromycin in patients with COVID-19: an open-label randomized trial. Antiviral Res. 2020;56:106143.

27. Cavalcanti AB, Zampieri FG, Rosa RG, et al. Hydroxychloroquine with or without azithromycin in mild-to-moderate Covid-19. $\mathrm{N}$ Engl J Med. 2020;383:2041-52.

28. Furtado RHM, Berwanger O, Fonseca HA, et al. Azithromycin in addition to standard of care versus standard of care alone in the treatment of patients admitted to the hospital with severe COVID-19 in Brazil (COALITION II): a randomized clinical trial. Lancet. 2020;396:959-67.

29. Ling KM, Hillas J, Lavender MA, et al. Azithromycin reduces airway inflammation induced by human rhinovirus in lung allograft recipients. Respirology. 2019;24:1212-9.

30. Porter JD, Watson J, Roberts LR, et al. Identification of novel macrolides with antibacterial, anti- inflammatory and type I and III IFN-augmenting activity in airway epithelium. J Antimicrob Chemother. 2016;71:2767-87.

31. Yamaya M, Nomura K, Arakawa K, et al. Clarithromycin decreases rhinovirus replication and cytokine production in nasal epithelial cells from subjects with bronchial asthma: effects on IL-6, IL-8 and IL-33. Arch Pharm Res. 2020;43:526-39.

32. Du X, Zuo X, Meng F, et al. Direct inhibitory effect of viral entry of influenza A and SARS-CoV-2 viruses by azithromycin. Cell Prolif. 2021;54:e12953.

33. Renteria AE, Endam LM, Adam D, et al. Azithromycin downregulates gene expression of IL-1 $\beta$ and pathways involving TMPRSS2 and PMPRSS11D required by SARS-CoV-2. Am J Resp Crit Care Med. 2020;63:707-9.

34. Tsiakos K, Tsakiris A, Tsibris G, et al. Oral clarithromycin in COVID-19 of moderate severity: the ACHIEVE open-label trial using concurrent matched comparators. medRrxiv. 2020. https://doi.org/ 10.1101/2020.12.22.20248753.

35. Lee N, Wong CK, Chan MCW, et al. Anti-inflammatory effects of adjunctive macrolide treatment in adults hospitalized with influenza: a randomized controlled trial. Antiviral Res. 2017;144:48-56.

36. Ulrich H, Pillat MM. CD147 as a target for COVID19 treatment: suggested effects of azithromycin and stem cell engagement. Stem Cell Rev Rep. 2020;16: 434-40. 